\title{
Social Participation in University Governance: China's Situation and Its Path Selection
}

\author{
Zehui An \\ The Higher Education Research Institute of Jilin Agricultural University; Jilin Changchun; China \\ zehuian@126.com
}

Keywords: University governance; Social participation; Path choice

\begin{abstract}
With the development of society, College named the ivory tower that it gradually is abandon, build new relationship between society and college, the most important index of evaluation college ability of management social resource participation management of college. Nowadays, in framework of college management, although part of college lead into social strength in a degree, because of tradition concept limit, system of social participation imperfect and limitation of social economy, college Participation degree is different, the path of participation is different, generally speaking, society participate in management of college is budding stage, college and government exhibit imbalance, namely school is stronger than society. So through many paths encourage and guarantee social participation is very important: Strengthen consciousness of social participation, government properly get involved and support, perfect Production cooperation system, sound society supervision system.
\end{abstract}

\section{Best State of the Relationship between College and Society: Be neither too Familiar nor too Distant}

Professor Gong Fang refers in Social Responsibility of Modern University; it is the best ideal mode that keeps "Be neither too familiar nor too distant" between college and society, author keep this point as the same. with the development of society, College named the ivory tower that it gradually is abandon, college should come out and over the ivory tower, college and society "zero distance" relationship is undesirable, the both need to keep a distance, namely keep "Be neither too familiar nor too distant". "Do not leave" enable the university to grasp the real situation, a better understanding of the community, and take the time to give the university the social responsibility, "Not that" avoid blinders, to avoid the excessive mechanization of education, utilitarian, and tools, avoid "Blinded by lust for money".

Universities must take on the social responsibility of the times. The traditional university Autonomous theory that university is not only knowledge, knowledge of interference after the application of the result of the dispute, the university does not assume any social responsibility. But the new ethics of knowledge that university is to answer what, why, how to answer the question, namely the university itself to make judgments about the application of knowledge of the results, the value must not evade the intervention of social responsibility. [1] Value intervention, is to say the university should grasp the real situation, understand the needs of the community, and try to meet this demand, which is also the university should bear the social responsibility. In fact, the pure "independent university to maintain is" very difficult. The university is not detached from social organizations outside an organization but society, University in relations with other social organizations, the activities will directly or indirectly affect the pattern of social interests, the social responsibility of University also comes from this. Derek Burke in the book "out of the Ivory Tower: the modern university's social responsibility," clearly stated: "in the university if you want to fully understand their real role and purpose in society, it is necessary to examine their social responsibility." [2] and what kind of social responsibility should be borne by contemporary university? Experts stressed that the arrival of the era of globalization calls for the University and beyond out of the "ivory tower", the university must assume responsibility for education in the era, academic responsibility, international responsibility, service and the guiding role of the society; 
Experts stressed that the arrival of the era of globalization calls for the University and beyond out of the "ivory tower", the university must assume responsibility for education in the era, academic responsibility, international responsibility, service and the guiding role of the society; [3]Some scholars believe that the main social responsibility of university is the cultivation of talents, scientific research and knowledge innovation, only with a reasonable extension of the social service function of teaching and research activities in the University, and that different types and levels of China's colleges and universities should meet the needs of different levels and types of social needs, undertake different levels and types of social responsibility. [4]

There is no doubt that the University to assume the social responsibility is the consensus, but the University and the government must maintain some degree of separation. Only to maintain a certain distance, university to see the community clearly and really, the more sober and rational thinking for the University, rational thinking and criticism are the right ways to assume social responsibility of the university. Former Harvard president Nash - M - Pasi believes that the "real world" and "academic world" are connected but different, "Academic world" to stand out of the "real world" to observe and reflect the "real world" of all, in order to explore what kind of thinking to learn, which can make the "real world" better, more humane. [5]Japanese educational sociologist Nagai Daoxiong warned people: "if the University and society being too closely, academic reflects the practical too much, Creative University will be gradually dried up, independence will be gradually lost, and even become a social." [6]Especially in the context of China's social and economic transformation, some schools slide into the economic interests of the supremacy of the track, ignoring the talent training, which is also the University of the loss of independent thinking ability, the loss of academic performance. It seems that in the current social context, the University and the society "maintain appropriate distance" against the main theme of education reform.In fact, only the "maintain proper distance" can avoid education drift, the social development and change in order to make rational thinking, in order to make the University offers a real scientific and academic social services to the society.

\section{The status quo of China's University and Social Relations: the Lack of Social Participation}

Due to historical reasons, before the reform and opening up, China's University is a subsidiary body of the government, the management authority in the hands of the government; social participation right has long been ignored. This simple, efficient, highly centralized management way of the government at that time did support the basic needs of the development of the country, but also bring the university administration, the lack of innovation and vitality of the University, and many other drawbacks. After reform and opening up, the reform of the management system of higher education, the government is no longer the only responsible person, the university expanded the autonomy of running a school, and shoulder more social responsibility. Society is also involved in the governance of the University, and has shown an unprecedented positive trend, if the community is represented in the university board of directors, participate in the decision-making and supervision of the school, to set up the research cooperation; to participate in the macro policy making; to evaluate the quality of university personnel training and the level of running a school. However, due to the shackles of traditional concepts, social participation mechanism is not perfect and economic constraints, social participation in university governance is still at the embryonic stage, facing many difficulties: (1)Because of the structure of our university's long-term dependence on the government, as well as the "extremely strong government, extremely weak society", it is easier for the public to understand that education is the responsibility of the government and universities, and the lack of rational understanding of their own responsibilities, in the concept of participation in university governance, the main consciousness is weak, the lack of enthusiasm; (2) after the reform and opening up, the vertical relationship of Chinese university management system reform focus on the coordination of central and local governments, the coordination of the University ", not paid enough attention to the coordination of the horizontal relationship between University, government and society, and the management right is still in the government and the University with the weakening of social participation power; (3) the evaluation, 
supervision and feedback mechanism of the society has not been established, the content and the way of participation are not ideal, and the social participation system is not complete;(4) Individuals, enterprises, other social organizations are more indirect communication with universities but direct participation is less, the depth of social participation is not enough. Some scholars have summed up the current situation of our country's social participation in the governance of the university through the investigation of the 81 universities in China: Also some scholars through the investigation of the 81 universities in China, summed up the status quo of China's social participation in the governance of the University: the overall level of participation is not high, limited channels. Specific performance in: (1) the formal institutional channels of participation are limited, and the University Council and the similar institutions fail to play their due role; (2) the function of the society to the evaluation and supervision of colleges and universities has not been effectively applied, and the social participation in the decision-making field is the most weak. (3) experts and scholars and enterprises to participate in university governance opportunities, the media, communities, parents, creditors (such as banks) and other social groups to participate in fewer opportunities. [7]

In a word, the relationship between University and government in our country is not balanced, that is, the school is stronger than the society. Although the government explicitly requires colleges and universities to run the school for the society, but the University's reflection of the community is slow, resulting in this phenomenon is an important reason for the strong government standard. In China, the higher education in Pyramid, the government decided the reputation of the school level and the allocation of resources, there is no doubt that the resources of the University's reputation as behavior will be climbing stairs, therefore, requirements for social education of colleges and universities is also very difficult to succeed. [8]At the same time, because of strong government standard, the university answerable to the government, the government is sandwiched between the society and the college, became a university to serve the society of University of our country is more obstacles, will serve as the government and society. Although the government has called on the university to directly serve the community, and provide that some development projects should be led by the enterprise, due to the vertical task than the horizontal topic will bring more honor to the school, the university is still facing the government, the project does not have the interest of the government is not involved in the project. This is mainly because the government has taken the wrong way of solving it. The government does not withdraw from the management, but to take the administrative command mode, will inevitably lead to further strengthening the role of the government. The correct way to solve the government is no longer under the command, but the resources will be put back to the community, the university will naturally find a society.[9]

\section{The Realization Path of China's Social Participation in University Governance}

In the common governance structure of "University, government and society", although part of the schools to a certain extent lead in the social forces, the degree of participation and depth of participation both are different. Generally speaking, the society is in a passive and weak position, so it is very important to encourage and protect the social participation through a variety of ways.

Strengthen the Awareness of Social Participation. There are three main reasons for strengthening the consciousness of social participation. Firstly, the social participation in university governance has become an inevitable requirement. With the development of market economy, the society has diversified demands for knowledge and talents to meet the diversified needs of higher education, which is far from enough by colleges and universities and the government's strength, but needs for social forces to participate in a wide range of; At present, the international competition is the talent competition, but also the quality of the higher education. When higher education has become an important source of economic and social development, the development of higher education and education will also be the common responsibility of the community. The whole society should be concerned about the development of education. At present, the diversification of the sources of the funds of higher education is the extensive participation and supervision of the society. Secondly, the social participated in university governance has important practical significance. Through social participation can promote the formation relative balanced relationship 
between the three of the University, government and society, to a certain extent, inhibits the excessive administrative tendency of University governance; Social participation can overcome the tendency of excessive autonomy in university; [10]To a certain extent, social participation can eliminate the drawbacks of over - sealing in the development of universities. In short, the participation of the community in university governance is conducive to the scientific and democratic management decision-making. Thirdly, when the laws and regulations and the operation mechanism of social participation in university governance are not perfect and the change of ideas will be an important factor that affects the effective participation of the society. No matter is the university or the society itself should be aware that the university must face the society to run a school, to take the initiative to adapt to the needs of the community, so as to serve the development of society. Universities and the public to change the traditional of concept "higher education is only the internal and government responsibility", University to go out of the ivory tower, in the management, should actively absorb the participation of social forces, the community itself to participate in the concept of governance of the university and enhance the awareness of the main body, to improve the enthusiasm. In addition, the degree of social participation in higher education is closely related to and personal qualities in the social, after changing ideas, social participation personnel and groups should strengthen education and training, improve their own quality, master the necessary theoretical knowledge and skills, to participate in the creation of conditions for University governance.

Appropriate Government Intervention and Support. According to the survey of 81 college leaders found that nearly half of the leaders believe that "The government has not yet established a sound system and mechanism for social participation in university governance" and "The government has not yet given a part of the governance of the university to the community" are an important factor affecting the social participation in university governance, so the government is responsible for the promotion of social participation in university governance, to continue to relax the University, to give its autonomy. [11]At the same time based on the new public management theory, he role of the government is not "oarsman" but " the helmsman", An effective government is not in person to perform, but to be able to "manage" and be good at "governance"", therefore, the function of the government in the university governance lies in the macro regulation and control, the development of educational policies, laws and regulations, and to provide the power space for social participation in education management ". In the process of promoting social participation in University governance, first of all, the government should actively listen to the views and suggestions of higher education from all walks of life, absorbing the social forces to participate in educational decision-making, to promote scientific and democratic decision-making. Just as in 1985, the CPC Central Committee decided on the reform of educational system, during drafting process, has widely listened to the views of the community, has held many seminars and the decision-making process has been a scientific research, and achieved good results. Secondly, in the management level, the government can set up Specialized Committee in educational administration, invite entrepreneurs, economists and social scholars as members, for directly involving in the management of colleges and universities to give counsel. Public higher education in the United States, the establishment of higher education management committee, by the state government through the Commission on education management and coordination, most of the members of the Committee for the community, the community participation in the governance of the University of China has some enlightenment.[12]

Improve the Mechanism of Production and Research Cooperation. Industry university research cooperation can be described as an old and constantly updated topics, in China, the first began in the last century in $90 \mathrm{~s}$, after decades of development. It has played an important role in enterprise technological innovation, the birth of Peking University Founder, Thunis and other well-known domestic enterprises, at the same time, the cooperation can make the University keenly aware of social needs, playing an important role in promoting the cooperation of University and society. However, China's current research cooperation in the institutional mechanism is still a problem, such as the main body of the research cooperation in the system of the existence of 
barriers, interest allocation mechanism and risk sharing mechanism are not mature; Protection of intellectual property rights is not enough, etc., therefore, to rationalize and improve the mechanism of production and research cooperation is an objective requirement to strengthen the depth of cooperation between universities and society. Through the system, laws, regulations, agreements, etc. it is clear that the interests of the parties to the research and industry cooperation, and to restrict their cooperative behavior, to safeguard the common interests; To establish the distribution of interests and reasonable risk sharing mechanism, and deal with the pricing of scientific and technological achievements, according to the relevant provisions of the clear ownership of property rights, technical responsibility, economic interests, to improve the sense of risk sharing. Because the interests of both sides to grasp the information asymmetry, very easy to cause a party to maximize the interests of the interests of the other side of the phenomenon, moral hazard has become an important factor in the failure of industry university research cooperation. Therefore, it is important to take measures to improve the moral hazard; In addition, the policy oriented mechanism, incentive mechanism, communication mechanism, service mechanism, and other aspects of research cooperation also need to be further improved.

Sound Social Supervision System. University is a stakeholder organization, social public and social organizations as stakeholders, need for the university activities and related issues to make decision, manage, etc.. Through social forces on the University's supervision, not only can make universities aware of social needs, timely response to social improvement, but also is conducive to the relationship between University and social communication, social support, improve the social reputation of University. However, there are many problems in the social supervision of colleges and universities at present. From the perspective of the subject, the initiative and consciousness of the main body of social supervision is not high; From the process, the social supervision mechanism is not perfect, not standardized, the role of supervision canot be better play; From the results, the academic corruption, the quality of teaching and so on for the post supervision, supervision lag and social supervision effect is not obvious. [13] This provides a space for economic corruption and the occurrence of academic corruption. In order to solve the above problems, we should seek the corresponding measures based on the actual situation of the reform and development of higher education in our country. First, along with the reform of the administrative system of our country, the government should gradually decentralization, nurturing the development of professional intermediary organizations, to actively play the role of professional associations, foundations, industry associations and other types of intermediaries in the governance of the university. Firstly, along with the reform of the administrative system of our country, the government should gradually decentralization, nurturing the development of professional intermediary organizations, to actively play the role of professional associations, foundations, industry associations and other types of intermediaries in the governance of the university. the "education planning outline" promulgated in 2010clearly pointed out that to foster professional education service institutions, in order to improve the school's external supervision to provide policy support. Secondly, establish the interaction between the University and the community response mechanism. To actively promote the university information disclosure, in 2011 the Ministry of Education promulgated the University Information Disclosure Measures, the government requiring universities to establish a legal form of information disclosure system. At the same time, the development of WeChat, micro-blog and other new media means for the information disclosure system also provides an opportunity for the construction. Some colleges and universities in China have established the information open network, accept the social evaluation and supervision, not only to promote the University and the social links, but also to promote the university to achieve a healthy development of social interaction. Although China's national conditions and higher education management system is not the same with foreign countries foreign experience can also be used for reference, we should constantly improve the system of the university board of directors in our country to make it become an entity, carrier, and in the University, development planning, decision-making, scientific research, discipline construction, consultation, consideration and other aspects to play the real role. 


\section{Acknowledgements}

Supported by Youth Foundation of Jilin Agricultural University(No.201652); Supported by Jilin Association of Higher Education(No.JGJX2016D38)

\section{References}

[1] H.C. Wang: President of the University. Mission and Role Selection(Shanghai Jiao Tong University press, China 2009).(In Chinese)

[2] Derek Bok(translated by Xiaozhou $\mathrm{Xu}$, Jun Chen): Beyong the Ivory Tower (Zhejiang Education Press, China 2001).(In Chinese)

[3] J.S. Wang: Journal of Higher Education,Vol.24(2003)No.1,p.2. (In Chinese)

[4] F. Gong: Peking University Education Review,Vol.43(1994)No.3,p.119. (In Chinese)

[5] Nash-M-Pasi: Higher Education in the United States(The Higher Education Research Laboratory of Hangzhou University, China 1985).(In Chinese)

[6] G.J. Shen: Encyclopedia of Chinese and Foreign Famous Educator(Liaoning Education Press, China 1995).(In Chinese)

[7][11] Y.Y. Ding: Journal of National Academy of Education Administration,No.8,2014,p.72. (In Chinese)

[8][9] J.M. Zhao: China Higher Education Research, No.11,2014,p.2. (In Chinese)

[10] H. Zhu: Jiangsu Higher Education, No. 3,2012,p.59. (In Chinese)

[12] C.B. Liu: University Education Science, No. 5,2008,p.29. (In Chinese)

[13] H.Q. Xu: China Higher Education Research ,No.1,2013,p.83. (In Chinese) 